\title{
ALTERNATIVE ESTABLISHMENT STRATEGIES FOR WHITE CLOVER SEED PRODUCTION
}

\author{
John McCartin \\ Lincoln College Mixed Cropping Farm, Lincoln College
}

\begin{abstract}
Autumn sown white clover after wheat results in good white clover establishment and large areas can be sown. Direct drilling white clover into barley stubble in the autumn also gives very good white clover establishment. Other methods which include ryegrass and white clover sown together in autumn, sowing with autumn wheat undersowing barley and processed peas in the spring an oversowing autumn wheat in the spring are less successful. Keywords: White clover, Trifolium repens, seed production, establishment methods.
\end{abstract}

\section{INTRODUCTION}

On the Lincoln College mixed cropping farm of 216 hectares, all of which is in crop, up to half is in cereals, with the balance in legumes for seed, processing crops and some miscellaneous crops. The soils cover a wide range from Wakanui silt loam, Paparua sandy loam to Templeton shallow silt loam or sandy loam, with irrigation on 140 hectares.

The aim is to harvest up to 80 hectares of white clover seed per season. In order to reduce costs of cultivation and improve crop management several difference strategies have been tried to establish and manage white clover seed crops.

\section{ESTABLISHMENT AND MANAGEMENT STRATEGIES}

1. Establishing ryegrass and white clover together has been very successful in the past. The seed is mixed together down through Blackmore coulters when sowing. After harvesting ryegrass seed in the first year, the crop is grazed until May. In mid July, when the first frosts occur, flat weeds and ryegrass are sprayed with 2, 4-D butylester at $1.1 \mathrm{~kg}$ active ingredient/ha (1.5 $1 / \mathrm{ha})$ and carbetamide at 4.2 $\mathrm{kg}$ ai/ha (Carbetamex $706 \mathrm{~kg} / \mathrm{ha}$ ) leaving a pure stand of white clover.

The crop is grazed from mid August until mid to late September and then closed for white clover seed production. If the crop grows too quickly and gets too bulky after the September closing date, it is topped instead of grazed again. This is because sheep tend to eat the end off the stolons as they are starting to grow rapidly and produce flowers. Aphids and case bearer moth have to be sprayed with bromophos (Nexion) in the late November/early December period in most seasons. To help flowering, irrigation may have to be applied about the last week of November to the second week of December. Crops established in this manner yield up to $450 \mathrm{~kg} / \mathrm{ha}$ of white clover seed.

2. Sowing white clover seed with autumn wheat in May in $15 \mathrm{~cm}$ row spacings has been only partially successful. The white clover seed was sown at $3 \mathrm{~kg} / \mathrm{ha}$ from a Eclipse Box mounted in front of the seed box of the 701 drill, with each tube placed in the coulter to mix the seed with the wheat. However, a good clover strike did not result because of high competition from the wheat, as both wheat and white clover were growing together in the same coulter seedbed slot. May sowings with autumn wheat yield up to $400 \mathrm{~kg} / \mathrm{ha}$ of white clover seed.

3. Sowing white clover seed in $30 \mathrm{~cm}$ row spacings at $3 \mathrm{~kg} / \mathrm{ha}$, with autumn wheat, has been more successful. Every second tube from the Eclipse Box is mounted behind the coulters so that the white clover seed is broadcast on top of the ground. Suntrail harrows cover the seed. The white clover establishes very well between the wheat rows. However, when it comes time to spray the wheat for weeds such as mayweed, chickweed, speedwell, spurry and chamomlie, the clover is still not at the desired full leaf stage for spraying. MCPB at $1.2 \mathrm{~kg}$ ai/ha $(3 \mathrm{l} / \mathrm{ha})$ and 2, 4-D Amine at $0.4 \mathrm{~kg}$ ai $/ \mathrm{ha}(1 \mathrm{l} / \mathrm{ha})$ were first used, but did not give a good weed kill. Bromoxynil and MCPA at $0.5 \mathrm{~kg}$ ai/ha (Buctril M $2.5 \mathrm{l} / \mathrm{ha}$ ) has been more successful.

After wheat harvest the straw is baled and the paddock lightly grazed in February. The clover is often irrigated at this time to help the clover to establish, then heavily grazed from 
late April through to mid June. Broad-leaved weeds and grass are removed with 2, 4-D butylester at $1.1 \mathrm{~kg}$ ai/ha $(1.5 \mathrm{l} / \mathrm{ha})$ and carbetamide at $4.2 \mathrm{~kg}$ ai/ha (Carbetamex 706 $\mathrm{kg} / \mathrm{ha}$ ) in late July. Heavy rolling is done from August onwards when the ground is not too wet.

Care must be used with Urea on wheat, because at high rates ( $80 \mathrm{~kg} \mathrm{~N} / \mathrm{ha}$ and above), even though the wheat yields are high, the clover is burnt off.

4. Establishing clover under a barley crop does have some difficulties. Barley can smother out the clover, especially if a lot of nitrogen is used to get high barley yields. Barley seed sown at $120 \mathrm{~kg} / \mathrm{ha}$ with nitrogen gave the best results. Weeds, however, are considerably reduced in the barley crop method when compared with the wheat crop method. Good white clover establishment will result if the clover is sown in $30 \mathrm{~cm}$ row spacings and if the barley is sown at a medium sowing rate. Yields for crops established under barley have declined from around 400 to $250 \mathrm{~kg} / \mathrm{ha}$.

5. Undersown white clover with peas has been very successful. By spraying the peas with dinoseb (Sinox, 4 1/ha) and MCPB (3 1/ha) or terbutryn (Igran, 0.5 1/ha), weed control has been very good. The clover should be grazed after the pea harvest and the weeds controlled by autumn spraying. If the peas are processed then the heavy viners can leave deep wheel tracks which are difficult to roll out. In pea paddocks which are for seed only, the white clover can be very green and lush at pea harvest and therefore the pea crop must often be desiccated before harvest. White clover seed yields are up to $600 \mathrm{~kg} / \mathrm{ha}$.

6. Oversowing wheat in the spring with clover seed from a Vicon spreader is another of our establishment strategies. The wheat is then harrowed and rolled to spread the clover in to the ground and to remove some of the weeds. Yields have been up to $500 \mathrm{~kg} / \mathrm{ha}$.

7. Autumn sown clover after wheat is one of our best establishment strategies. In early February the wheat stubble is grazed hard and burnt. The next day the clover is direct drilled into the burn with a Multi-Seeder 734 with light harrows behind and then irrigated. The seedbed may be double rolled after sowing if the ground is too loose as the clover will strike better in firm soil. In mid June the clover is grazed and weeds sprayed. Grazing continues until the third week in August; the field is allowed to freshen up and then sprayed with paraquat in September. If the clover is not dense enough at this time, glyphosate at $0.4 \mathrm{~kg}$ ai/ha (Roundup $1 \mathrm{l} / \mathrm{ha}$ ) is applied in late September and barley direct drilled. Barley yields of up to 5.7 tonnes/ha have been obtained. After the barley harvest the straw is spread and the stubble irrigated. A good strong clover stand establishes and is taken for seed the next year.

8. Direct-drilling clover straight into barley stubble has given very good strikes. The clover is grazed from April until September. Clover yields of $700-935 \mathrm{~kg} / \mathrm{ha}$ have been harvested from both these direct-drilled crops.

\section{SUMMARY}

The above establishment strategies and the white clover seed yields are summarised in Table 1

TABLE 1 White clover seed yields from different establishment strategies.

\begin{tabular}{|c|c|c|}
\hline \multicolumn{2}{|c|}{ Establishment strategy } & \multirow{2}{*}{$\begin{array}{c}\text { White clover seec } \\
\text { yields (kg/ha) } \\
350 \text { to } 450\end{array}$} \\
\hline 1 & $\begin{array}{l}\text { Ryegrass and white clover } \\
\text { Ryegrass seed 1st year } \\
\text { White clover seed 2nd year }\end{array}$ & \\
\hline 2 & $\begin{array}{l}\text { Autumn sowing with wheat in } 15 \mathrm{~cm} \\
\text { row spacing }\end{array}$ & 300 to 400 \\
\hline 3 & $\begin{array}{l}\text { Autumn sowing with wheat in } 30 \mathrm{~cm} \\
\text { row spacing }\end{array}$ & 300 to 400 \\
\hline 4 & $\begin{array}{l}\text { Spring sowing with barley in } 30 \mathrm{~cm} \\
\text { row spacing }\end{array}$ & 250 to 400 \\
\hline 5 & Undersowing white clover with peas & 300 to 600 \\
\hline 6 & $\begin{array}{l}\text { Oversowing wheat in the spring } \\
\text { with clover }\end{array}$ & 250 to 500 \\
\hline 7 & $\begin{array}{l}\text { Direct drilling clover seed into burnt } \\
\text { wheat stubble in February }\end{array}$ & 700 to 935 \\
\hline 8 & $\begin{array}{l}\text { Direct drilling clover seed into barley } \\
\text { stubble }\end{array}$ & 700 to 935 \\
\hline
\end{tabular}

1. White clover and ryegrass together are not suitable for large areas as clover yields are not high.

2. Undersowing autumn wheat in $30 \mathrm{~cm}$ rows with clover is very good for establishing clover over a large area. The clover strikes very well, but weeds can be a problem.

3. Good clover can be established from under-sowing processed peas in the spring.

4. Autumn-sown clover direct drilled after wheat or barley is the best establishment strategy giving the highest seed yields. $30 \mathrm{~cm}$ 
rows give the best establishment of white clover.

\section{ACKNOWLEDGEMENT}

Mr G.F. Tate, supervisor of the Mixed Cropping Farm, for both freedom and encouragement to develop effective clover sowing alternatives.

\section{DISCUSSION}

Q. Why is direct drilling of a crop stubble rather than burning first preferred?

A. The stubble provides a better moisture-shelter relationship and can subsequently reduce weed problems.

Q. How are the farmer members of the panel reducing production costs?

A. By autumn direct drilling into standing stubble with associated reduction in herbicide useage. 